\title{
Studies on the Histopathological Responses of Vigna Mungo towards Meloidogyne Incognita at Different Time Intervals
}

\author{
Ambreen Akhtar* and Hisamuddin
}

Department of Botany Aligarh Muslim University, Aligarh-202002, India

\begin{abstract}
The pot experiments on Vigna mungo with five replicates for each treatment were set up in the Department of

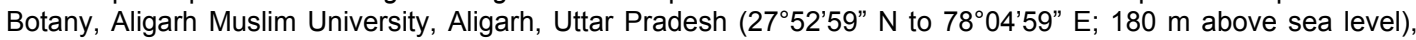
India. Histological studies of the roots of infected plants were carried out after 24 h, 48 h, 72 h, 5 days, 10 days, 15 days, 21 days, 25 days and 30 days of inoculation. The second-stage juveniles penetrated into the roots and moved intercellularly by separating the cell walls after $24 \mathrm{~h}$. The first sign of infection observed after $48 \mathrm{~h}$ of inoculation was hypertrophy in the cells, around the head of the juvenile. The cytological changes in the hypertrophied cells became more prominent after $72 \mathrm{~h}$ of inoculation, and the cells transformed into discrete giant cells. The giant cell cytoplasm became dense and stained darkly, the size of the nuclei and the nucleoli increased after five days of inoculation. Ten days after inoculation, the width of vessel elements was also increased. The second-stage juveniles moulted into the third stage. After 21 days of nematode exposure, the hypertrophied and hyperplastied parenchyma cells were observed adjacent to the giant cells. At several occasions, the giant cell complexes appeared to be surrounded by abnormal xylem comprising of abnormal vessel elements, which were transformed from the hypertrophic and hyperplastic parenchymatous tissue. The head region of the nematode was in contact with the giant cells while remaining part of the body expanded and caused disruptions in the arrangement of vascular and cortical tissues, as was observed after 25 days of inoculation. After 30 days of nematode inoculation, egg masses were found associated with all the mature females. The tissues were disrupted as the egg masses were pushed out to the surface of the root. Several eggs enclosed first stage juveniles.
\end{abstract}

Keywords: Giant cell complex; Histology; Hypertrophy; Hyperplasia; Meloidogyne incognita; Vigna mungo

\section{Introduction}

Meloidogyne incognita a sedentary endoparasite feeds upon the metabolites from specially modified parenchymatous cells in the root tissue called giant cells. By its esophageal glandular secretions [1], it altered the root tissue integrity and deviated its functioning to perform improperly. As the infectivity increased, day by day, the normal cells converted into multinucleate hypertrophied cells and ultimately took the form of a gall, observable as an outgrowth at the infected site of the root. The affected cells exhibited changes mainly in the form of hypertrophy and hyperplasia. The juvenile on entering the root tissue, made its own path without destroying the host cells and set in the cortical and stelar region permanently. It secreted enzymes and changed the metabolism of host cell according to its need $[1,2]$. The parasitized cells called as giant cells became multinucleate because of karyokinesis without cytokinesis [3]. According to Bird [4] the mature female is responsible for the development and maintenance of the giant cell system; histone like basic proteins exuded from the buccal stylet of the nematode which the controlled the events. The cells divided into new cells but just get bigger and contained more nuclear material. This allowed the giant cell to produce large amount of protein required for the nematode. The metabolic rate of that particular cell (giant cell) increased. The xylem and phloem elements functioned abnormally [5]. Xylem transports water and nutrients towards the infected cells besides other normal cells. The giant cells received metabolites and functioned as sink. The cytoplasm of the matured giant cell became dense and granular, and contained much protein [6]. Plant parasitic nematode, Meloidogyne incognita, takes its food from that multinucleate giant cell, where a group of small and large giant cells induced by the nematode is referred to as giant cell complex. The cell walls of the giant cells become thick at the later stage of development and make inward projections. Nuclei and nucleoli become large and prominent.

This experiment was aimed to examine the effects of the nematode on the anatomy of the root tissue from $1^{\text {st }}$ to $30^{\text {th }}$ day after inoculation. In the experiment, formation of the giant cell, gall formation, and production of abnormal xylem and phloem were examined.

\section{Materials and Methods}

\section{Raising of seedlings}

The seeds of Vigna mungo L. PU-30 were procured from National Seeds Corporation, I.A.R.I., New Delhi. The seeds were surface sterilized with $0.1 \%$ mercuric chloride for two minutes and washed three times with sterile distilled water. Five seeds per pot were sown in $30 \mathrm{~cm}$ earthen pots containing $1 \mathrm{~kg}$ steam sterilized soil. After germination, the seedlings were thinned to one per pot.

The pot experiments were set up in the first week of April in the Department of Botany, Aligarh Muslim University, Aligarh, situated at northern part of the state of Uttar Pradesh (27 $52^{\prime} 59^{\prime \prime} \mathrm{N}$ to $78^{\circ} 04^{\prime} 59^{\prime \prime}$ E; $180 \mathrm{~m}$ above sea level), India. Five replicates were taken for each treatment.

*Corresponding author: Ambreen Akhtar, Department of Botany Aligarh Muslim University, Aligarh-202002, E-mail: ambreen.qazi08@gmail.com

Received November 23, 2015; Accepted December 05, 2015; Published December 10, 2015

Citation: Akhtar A, Hisamuddin (2015) Studies on the Histopathological Responses of Vigna Mungo towards Meloidogyne Incognita at Different Time Intervals. J Plant Pathol Microbiol 6: 319. doi:10.4172/2157-7471.1000319

Copyright: ( 2015 Akhtar A, et al. This is an open-access article distributed under the terms of the Creative Commons Attribution License, which permits unrestricted use, distribution, and reproduction in any medium, provided the original author and source are credited. 


\section{Nematode inoculum}

The sedentary endoparasite Meloidogyne incognita was selected as test pathogen. Sufficient number of egg masses of $M$. incognita were handpicked, with the help of sterilized forceps and placed in $10 \mathrm{~cm}$ diameter 15 mesh coarse sieves, which were covered with crossed layers of tissue paper. The sieves were placed on petridishes containing sufficient water so that their lower part remained partially submerged in water. To avoid evaporation of water the petridishes were covered and kept in an incubator running at $25^{\circ} \mathrm{C}$. After $24 \mathrm{~h}$ onwards secondstage juveniles were collected in the form of suspension and stored for later use, and fresh water was added. The number of juveniles was counted using counting dish. The amount of water in suspension was adjusted in a way that $1 \mathrm{ml}$ suspension contained $100 \pm 5$ nematodes or $10 \mathrm{ml}$ contained 1,000 freshly hatched second-stage juveniles.

\section{Inoculation method}

One week old seedlings in each pot were inoculated with $10 \mathrm{ml}$ nematode suspension by pipetting. Uninoculated plants served as control. Watering was done as and when required.

\section{Harvesting process}

Five seedlings from each pot were harvested after $24 \mathrm{~h}, 48 \mathrm{~h}, 72, \mathrm{~h}$, 5 days, 10 days, 15 days, 21 days, 25 days and 30 days after nematode application. The roots were washed thoroughly and gently to remove soil particles. The galled roots were cut into one $\mathrm{cm}$ long pieces and processed for histopathological studies.

\section{Histopathological preparation}

The microscopic study of tissue is an important tool in anatomical study of infected plants.

\section{Fixation}

This is the process by which the constituents of cells and tissue are fixed in a state where they withstand subsequent treatment with various reagents with minimum loss of architecture.

The roots were collected and fixed in FAA [7].

\begin{tabular}{|c|c|}
\hline Ethanol 50\% & $90 \mathrm{ml}$ \\
\hline Formaline 37\% & $5 \mathrm{ml}$ \\
\hline Glacial acetic acid & $5 \mathrm{ml}$ \\
\hline
\end{tabular}

The roots were placed in the fixative for a minimum period of $24 \mathrm{~h}$ to several days, depending on their thickness.

\section{Dehydration}

The first step in processing is dehydration. Water is present in tissues in free and bound (molecular) forms. The segments of roots were transferred stepwise through increasingly higher concentrations of alcohols. Tertiary butyl alcohol (TBA) dehydration schedule (Table 1) was followed [7]

\section{Infiltration}

In this process, paraffin replaces alcohol in the tissues so that the tissue becomes saturated with pure paraffin. After the $7^{\text {th }}$ step of TBA dehydration schedule, the solution was replaced with a 1:1 mixture of $100 \%$ TBA and paraffin oil. The tissue was allowed to remain in this solution for $1 \mathrm{~h}$ or more, depending on its thickness. Another container was filled $3 / 4^{\text {th }}$ of its volume with melted paraffin and allowed to solidify slightly. The roots picked up from the TBA-paraffin oil mixture were placed on the top of the solidified paraffin oil solution and placed uncovered in an oven at slightly above the melting point of the paraffin. After 1-3 h, the TBA-paraffin oil mixture was poured off and replaced with pure melted paraffin wax, and kept in oven for about $3 \mathrm{~h}$. This step was repeated once more.

\section{Embedding}

The roots were placed in molds of folded paper. The molds were first coated with a thin layer of glycerine to prevent sticking of wax to paper and then liquid paraffin wax was poured. The tissues were placed onto the surface of the wax with the help of heated forceps. Additional melted paraffin was added to cover the tissue and to fill the mold. Once the paraffin began to solidify, the molds were plunged into ice water and left there until solidification. After hardening, the blocks were cut into smaller pieces according to the position of the tissue.

\section{Sectioning}

Transverse and longitudinal sections of 10-12 $\mu \mathrm{m}$ thickness of the roots were cut serially with the help of rotatory microtome. The paraffin ribbon thus obtained was mounted on a clean glass coated with albumin and glycerine solution. The slides were left overnight in an incubator at $40^{\circ} \mathrm{C}$ to allow water to evaporate. These slides were placed at $60^{\circ} \mathrm{C}$ for one $h$ to melt the paraffin.

\section{Staining}

In this step paraffin wax is removed and to increase the contrast in the tissues dyes are used. In this process, safranin and fast green were used [8]. The slides were taken out from the xylene and laid onto an absorbent surface and stained as per given schedule (Table 2). After the last step, mounting medium was applied on slide and was covered, carefully, with cover slip. Finished slides were left to dry for at least 24 $\mathrm{h}$ at room temperature. For proper drying of mounting medium, the slides were kept in a tray and placed in incubator, at $60^{\circ} \mathrm{C}$, overnight. The slides were examined under Laborlux- $\mathrm{K}$ compound microscope. Necessary photographs were taken.

Photomicrographs were processed to clarify nematode penetration and development as related to cell structure; to study the plant response to $M$. incognita invasion.

\section{Results}

\section{After $24 \mathrm{~h}$ exposure}

After exposure of second-stage juveniles of Meloidogyne incognita to the plants, it was observed that the juveniles penetrated the plant root tip within $24 \mathrm{~h}$. The juveniles applied a force to make passage which caused change in the tissue (Figure 1). The passage made by a juvenile was followed by others. The juveniles penetrated preferably in the region of cell differentiation and elongation zone but were mostly

\begin{tabular}{|c|c|c|c|c|c|}
\hline Steps & \% Alcohol time & $\begin{array}{c}\text { Distilled } \\
\text { water } \mathbf{( m l )}\end{array}$ & $\begin{array}{c}\mathbf{9 5 \%} \text { Ethanol } \\
\mathbf{( m l )}\end{array}$ & $\begin{array}{c}\mathbf{1 0 0 \%} \\
\text { Ethanol (ml) }\end{array}$ & $\begin{array}{c}\mathbf{1 0 0 \%} \text { TBA } \\
\mathbf{( m l )}\end{array}$ \\
\hline $\mathbf{1}$ & $\begin{array}{c}50 \% \text { for } 2 \mathrm{~h} \text { or } \\
\text { more }\end{array}$ & 50 & 40 & 0 & 10 \\
\hline $\mathbf{2}$ & $70 \%$ overnight & 30 & 50 & 0 & 20 \\
\hline $\mathbf{3}$ & $85 \% 1-2 \mathrm{~h}$ & 15 & 50 & 0 & 35 \\
\hline $\mathbf{4}$ & $95 \% 1-2 \mathrm{~h}$ & 0 & 45 & 0 & 55 \\
\hline $\mathbf{5}$ & $100 \% 1-3 \mathrm{~h}$ & 0 & 0 & 25 & 75 \\
\hline $\mathbf{6}$ & $100 \% 1-3 \mathrm{~h}$ & 0 & 0 & 0 & 100 \\
\hline $\mathbf{7}$ & $100 \% 1-3 \mathrm{~h}$ & 0 & 0 & 0 & 100 \\
\hline $\mathbf{8}$ & $100 \%$ overnight & 0 & 0 & 0 & 100 \\
\hline
\end{tabular}

*TBA changes were carried out at $30^{\circ} \mathrm{C}$

Table 1: Tertiary butyl alcohol dehydration schedule [7]. 
Citation: Akhtar A, Hisamuddin (2015) Studies on the Histopathological Responses of Vigna Mungo towards Meloidogyne Incognita at Different Time Intervals. J Plant Pathol Microbiol 6: 319. doi:10.4172/2157-7471.1000319

\begin{tabular}{|c|c|c|}
\hline Step & Solution & Time \\
\hline $\mathbf{1 .}$ & Xylene & $5 \mathrm{~min}$ \\
\hline $\mathbf{2 .}$ & Absolute ethanol & $5 \mathrm{~min}$ \\
\hline $\mathbf{3 .}$ & $95 \%$ ethanol & $5 \mathrm{~min}$ \\
\hline $\mathbf{4 .}$ & $70 \%$ ethanol & $5 \mathrm{~min}$ \\
\hline $\mathbf{5 .}$ & $50 \%$ ethanol & $5 \mathrm{~min}$ \\
\hline $\mathbf{6 .}$ & $30 \%$ ethanol & $5 \mathrm{~min}$ \\
\hline $\mathbf{7 .}$ & $1 \%$ aqueous safranin & $1-12 \mathrm{hr}$ \\
\hline $\mathbf{8 .}$ & Rinse in tap water & \\
\hline $\mathbf{9 .}$ & $30 \%$ ethanol & $3 \mathrm{~min}$ \\
\hline $\mathbf{1 0 .}$ & $50 \%$ ethanol & $3 \mathrm{~min}$ \\
\hline $\mathbf{1 1}$ & $70 \%$ ethanol & $3 \mathrm{~min}$ \\
\hline $\mathbf{1 2 .}$ & $95 \%$ ethanol & $3 \mathrm{~min}$ \\
\hline $\mathbf{1 3 .}$ & $0.1 \%$ fast green FCF in $95 \%$ ethanol & $5-30 \mathrm{sec}$ \\
\hline $\mathbf{1 4 .}$ & Absolute ethanol & $15 \mathrm{sec}$ \\
\hline $\mathbf{1 5 .}$ & Absolute ethanol & $5 \mathrm{~min}$ \\
\hline $\mathbf{1 6 .}$ & Xylene-Absolute ethanol & $5 \mathrm{~min}$ \\
\hline $\mathbf{1 7 .}$ & Xylene & $5 \mathrm{~min}$ \\
\hline $\mathbf{1 8 .}$ & Xylene & $5 \mathrm{~min}$ or longer \\
\hline
\end{tabular}

Table 2: Safranin and Fast-Green Schedule [8].

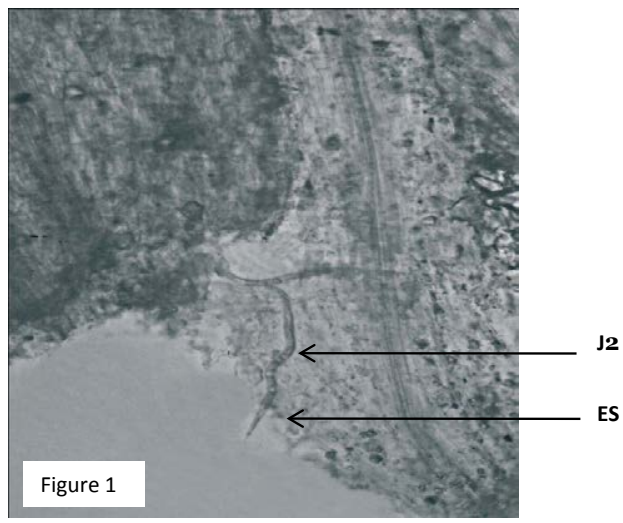

Figure 1: $\mathrm{J}_{2}$ : Second-stage juveniles ES: Entry site.

observed in the outer zone. The juveniles aimed to reach the region of vascular differentiation through a single aperture. The juveniles that had penetrated the root tip had orientated themselves in various directions vertical or parallel to the longitudinal axis of the root (Figure 2). The parenchyma cells of the outer part showed hypertrophy near the passage of the juveniles. Cell wall distortion was observed near the passage of the juveniles. The dimension, length and width of the juvenile was measured as $324 \times 21 \mu \mathrm{m}$.

\section{After $48 \mathrm{~h}$ exposure}

After $48 \mathrm{~h}$, destruction in the vicinity of the juveniles was resulted. The number of juveniles penetrated, after $48 \mathrm{~h}$, was found increased. In some cells, near head region of the nematode hypertrophy was observed (Figure 3). A few hypertrophied cells became larger and enclosed dense and granular cytoplasm towards the periphery of the cell. No trace of abnormal vessel elements were found adjacent to the hypertrophied cells. The thickness of infected root was slightly increased as compared to the un-infected one. In some sections hyperplastic cells were found near the enlarged cells. The width of the hypertrophied cell was measured as $102 \mu \mathrm{m}$. The measurement, length and width, of the nematode was observed as $331 \times 25 \mu \mathrm{m}$.

\section{After $72 \mathrm{~h}$ exposure}

The juveniles were found penetrating the same root after $72 \mathrm{~h}$. The hypertrophied cells changed into giant cells and their shapes changed to elongated instead of globular forms (Figure 4). The cell wall of the giant cells became thick. Adjacent to the giant cells hypertrophic and hyperplastic parenchyma cells were observed. The number of nuclei increased in the developing giant cells and there were 2-8 nuclei or more within one individual giant cell. The diameter of the infected root was found increased as that of healthy root. The size of the giant cells increased upto $105 \mu \mathrm{m}$. The nuclei appeared heavily stained. The width of abnormal vessel elements was recorded as $44 \mu \mathrm{m}$ while in normal vessel elements it was $21 \mu \mathrm{m}$. The dimension of the nematode was $338 \times 32 \mu \mathrm{m}$. The cytoplasmic density in cells next to the juveniles was increased.

\section{After 5 days nematode exposure:}

Lateral expansion of giant cells was observed. The diameter of giant cell was found to be increased upto $108 \mu \mathrm{m}$. The cytoplasmic contents became more dense and granular than that of surrounding cells. The wall thickening that occurred in the giant cells was more pronounced than in the adjacent cells. The vascular strands appeared disrupted. The width of xylem and cortical parenchyma was found increased. Few parenchyma cells were observed changing into vessel like elements. The

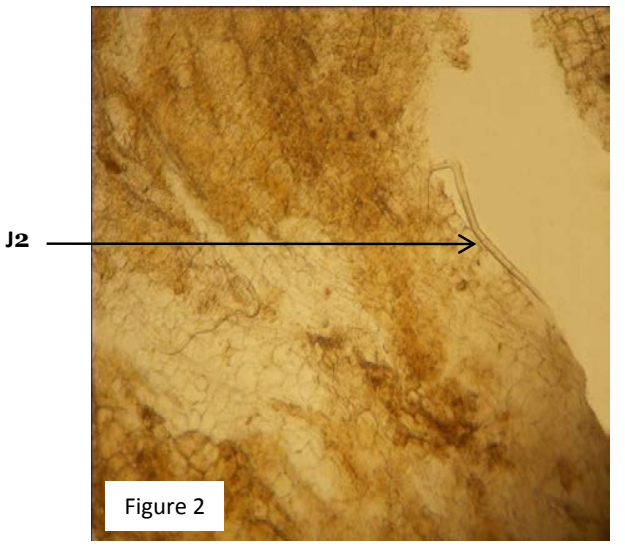

Figure 2: $\mathrm{J}_{2}$ : Second-stage juveniles.

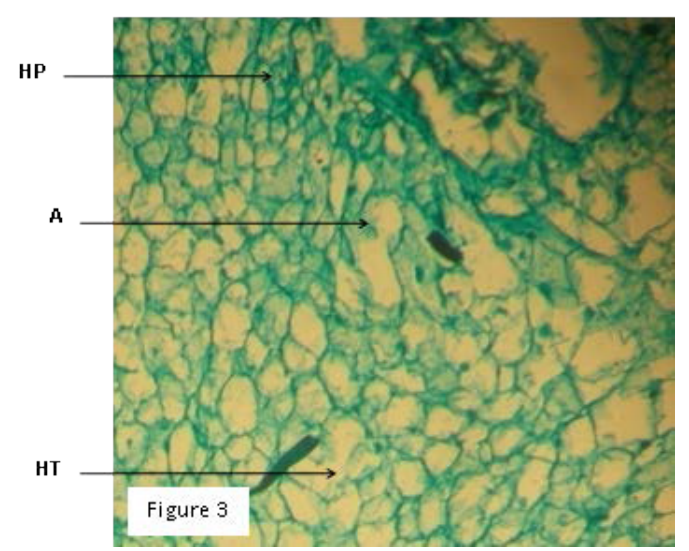

Figure 3: HP: Hyperplastied cells A: Giant cell transforming from undifferentiated cell HT: Hypertrophied cells. 
Citation: Akhtar A, Hisamuddin (2015) Studies on the Histopathological Responses of Vigna Mungo towards Meloidogyne Incognita at Different Time Intervals. J Plant Pathol Microbiol 6: 319. doi:10.4172/2157-7471.1000319

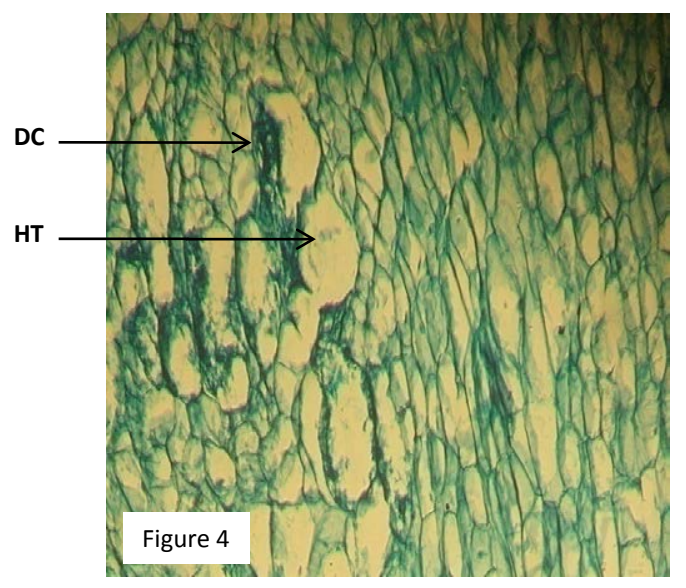

Figure 4: DC: Dense cytoplasm HT: Hypertrophied cells.

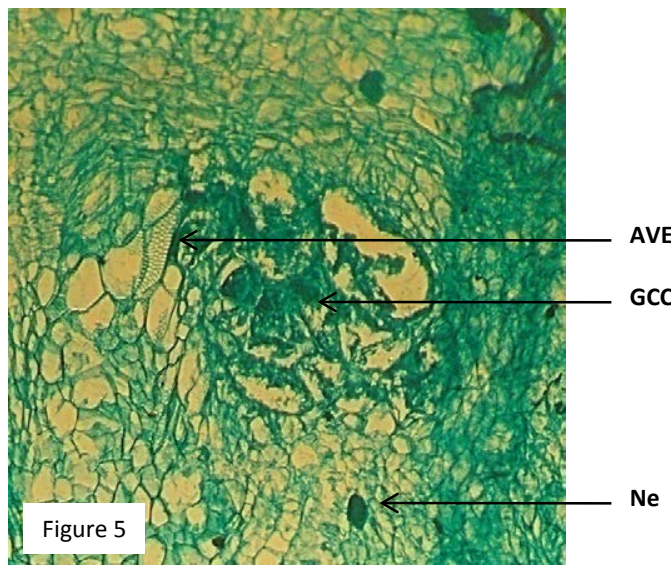

Figure 5: AVE: Abnormal vessel element GCC: Giant cell complex Ne: Nematode.

width of abnormal vessel elements was measured $47 \mu \mathrm{m}$, and of normal vessel element $25 \mu \mathrm{m}$. The number of larger nuclei, and nucleoli in the nuclei increased in the giant cells. The nematode width was increased and its dimensions were measured as $345 \times 47 \mu \mathrm{m}$. The parenchyma cells in the vicinity of the giant cells showed hypertrophy. The cells in contact with the nematode head showed hypertrophy and became multinucleate surrounded by abnormal vessel elements (Figure 5).

\section{After 10 days nematode exposure:}

After 10 days of infection, the width of galled root increased upto $2 \mathrm{~mm}$. The giant cells became larger and enclosed dense and granular cytoplasm. The nuclei and the nucleoli became larger and stained dark (Figure 6). The cellular integrity of the infected cells became completely changed. The nuclei were found in various shapes such as ovoid, elongated, triangular etc. The giant cell attained its size to $113 \mu \mathrm{m}$. The vacuoles in the giant cells were large. There was pronounced distortion in the arrangement of root tissue in infected portion. Maximum number of nuclei were observed aggregated in the centre of the giant cells. The width of vessel elements and size of cortical parenchyma cells was increased. The length of wider vessel elements was decreased. In several sections vascular strands were found broken (Figure 7). Some hypertrophied cells were found transferring into abnormal vessel elements. The width of abnormal vessel elements increased upto $52 \mu \mathrm{m}$ as compared to normal vessel elements being $29 \mu \mathrm{m}$. The dimension of the nematode changed and increased upto $352 \times 53 \mu \mathrm{m}$. Third stage juveniles were seen after 10 days of nematode exposure (Figure 8).

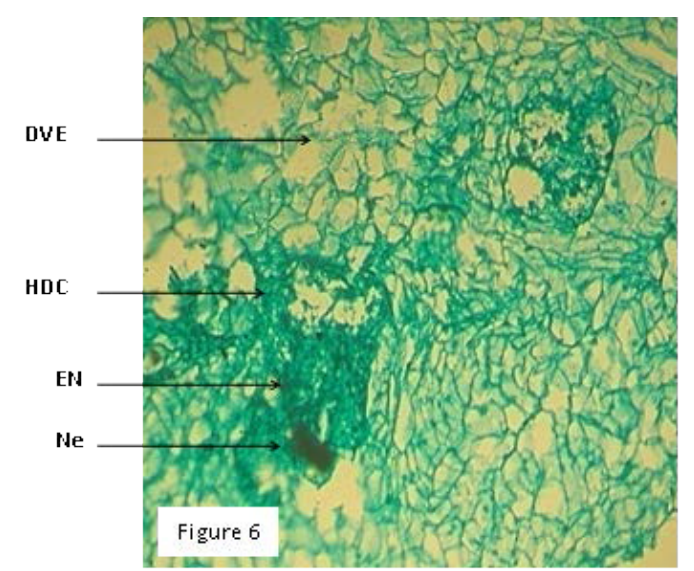

Figure 6: DVE: Distorted vessel element HDC: Highly dense cytoplasm EN: Enlarged nuclei Ne: Nematode.

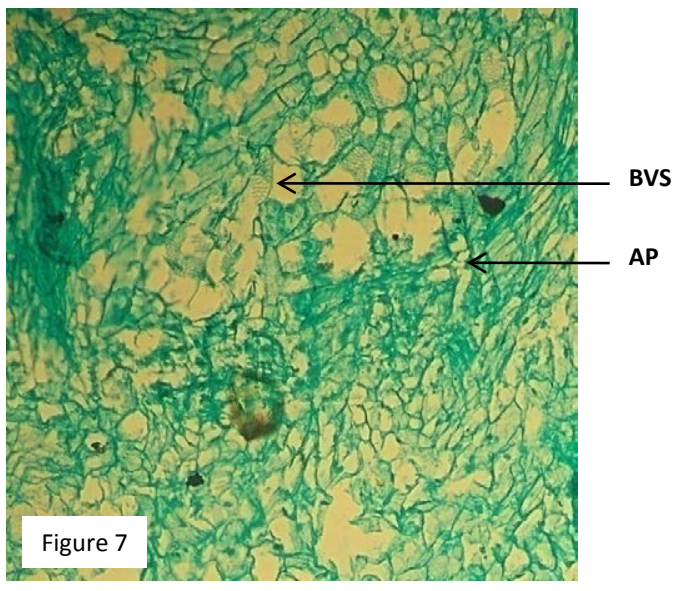

Figure 7: BVS: Broken vessel strand AP: Abnormal Phloem.

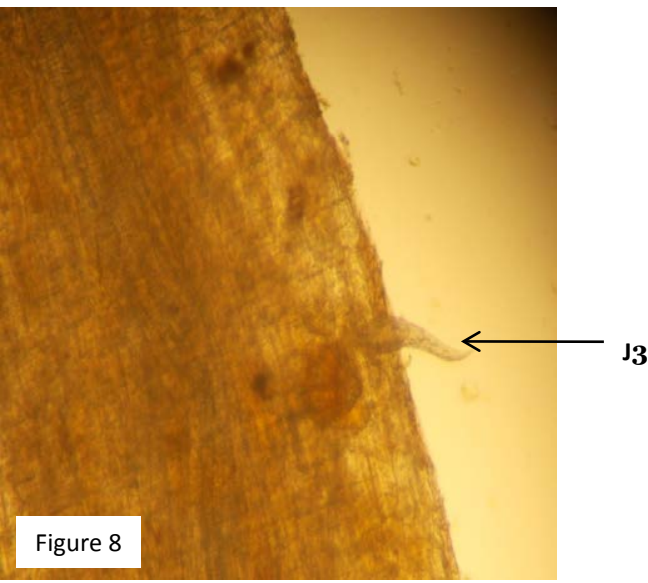

Figure 8: J3: Third-stage juvenile. 


\section{After 15 days nematode exposure}

A few giant cells were observed away from the main vascular strand, after 15 days of nematode exposure, but were found well connected with a branch of vascular strand. In longitudinal sections, normal vascular strands appeared broken. There were some abnormal vessel elements near the giant cells. The abnormal vessel elements were of different shapes and sizes. The diameter of the normal vessel elements and cortical parenchyma remained the same (Figure 9). The width of the giant cell was found to be increased to $117 \mu \mathrm{m}$ having dense cytoplasm and enlarged irregular nuclei with nucleoli. The width of abnormal vessel elements increased upto $57 \mu \mathrm{m}$ whereas that of normal elements was $32 \mu \mathrm{m}$. In some cells the cytoplasm of the giant cells was found towards the periphery. The nematode dimension increased to $367 \times 61 \mu \mathrm{m}$. The cells around the nematode body appeared compressed. The cytoplasm of the giant cells was aggregated along thickened cell walls and consequently the vascular tissues within the galls appeared disrupted and disorganized. Fourth stage juveniles were seen between 10-15 days of nematode exposure (Figure 10).

\section{After 21 days nematode exposure}

The width of the galled root increased. At this stage, giant cell complex was observed surrounded by abnormal vessel elements with characteristic wall reticulation. In few sections, giant cells were formed towards the periphery of the root. The nuclei in these giant cells were enlarged and had variable shapes and sizes. The size of abnormal vessel elements, adjacent to the giant cells, was large and their shape resembled with the shape of the giant cells. The size of giant cell measured as 120 $\mu \mathrm{m}$. The hypertrophical alterations were found in protoxylem and protophloem tissues. The width of abnormal vessel elements increased to $61 \mu \mathrm{m}$ and of normal vessel element to $35 \mu \mathrm{m}$. At this stage, the giant cell complexes were found in the cortical as well as in the stelar regions of the root (Figure 11). The wall of the giant cells appeared irregular and showed projections in a non-uniform pattern. Mature females were observed after 21 days of nematode exposure (Figure 12). The nematode size increased to $374 \times 72 \mu \mathrm{m}$. A number of abnormal, disorganized tracheary or vessel elements were developed around the giant cells and head region of the nematode. The different stages of development of the nematode were seen in a section (Figure 13).

\section{After 25 days nematode exposure}

The mature females resided permanently near the vascular tissue. The mature nematodes assumed oval shape. An empty cavity was

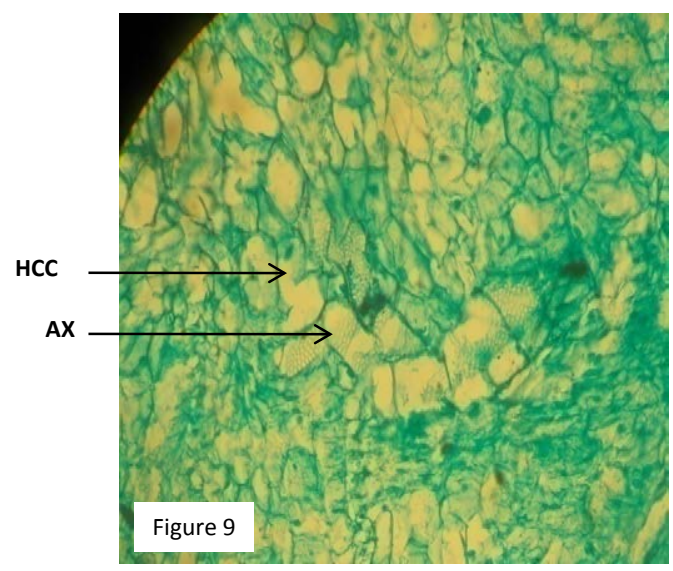

Figure 9: HCC: Hypertrophied cortical cells AX: Abnormal xylem.

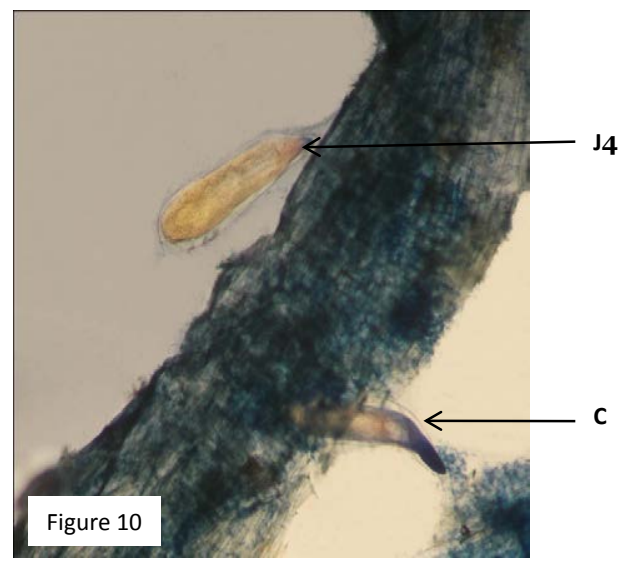

Figure 10: J4: Fourth-stage juvenile C: Cuticle.

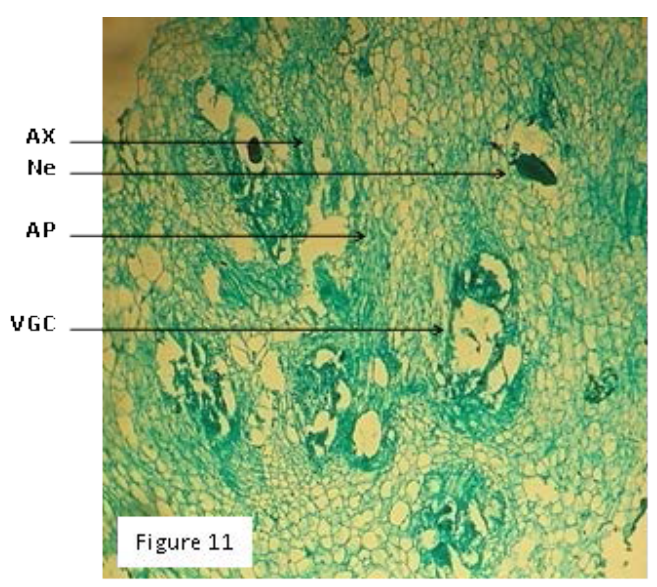

Figure 11: AX: Abnormal xylem Ne: Nematode AP: Abnormal phloem VGC: Vacuolated giant cell.

formed around nematode. The giant cells became empty (without or less amount of cytoplasm) (Figure 14). The average size of the giant cell was $127 \mu \mathrm{m}$. The nuclei and the nucleoli were prominent and stained darkly and attained the size of $15.37 \mu \mathrm{m}$. The feeding site induced by pyriform shaped $M$. incognita consisted of upto eight hypertrophied giant cells per adult female (Figure 15). The giant cells in the giant cell complex had distinct and thickened cell walls. Excessive amount of abnormal xylem was observed near the nematode head. The nematodes associated with the giant cells developed into adult females which acquired typical pyriform shape.

Between 24 to 30 days of infection, the mature females started egg laying which were deposited in a gelatinous sac and measured to $289 \mu \mathrm{m}$ in diameter (Figure 16). The dimension of the mature nematode was recorded as $531 \times 410 \mu \mathrm{m}$. The width of abnormal vessel element increased upto $64 \mu \mathrm{m}$ in comparison to normal one i. e. 37 $\mu \mathrm{m}$. Abnormal xylem elements were observed scattered around the giant cells (Figure 17). After 25 days of inoculation, vascular region of smaller lateral roots was found damaged. The giant cells with large vacuoles were observed in the same region (Figure 18).

\section{After 30 days nematode exposure}

The female nematode on maturation, started egg laying. Fully 
Citation: Akhtar A, Hisamuddin (2015) Studies on the Histopathological Responses of Vigna Mungo towards Meloidogyne Incognita at Different Time Intervals. J Plant Pathol Microbiol 6: 319. doi:10.4172/2157-7471.1000319

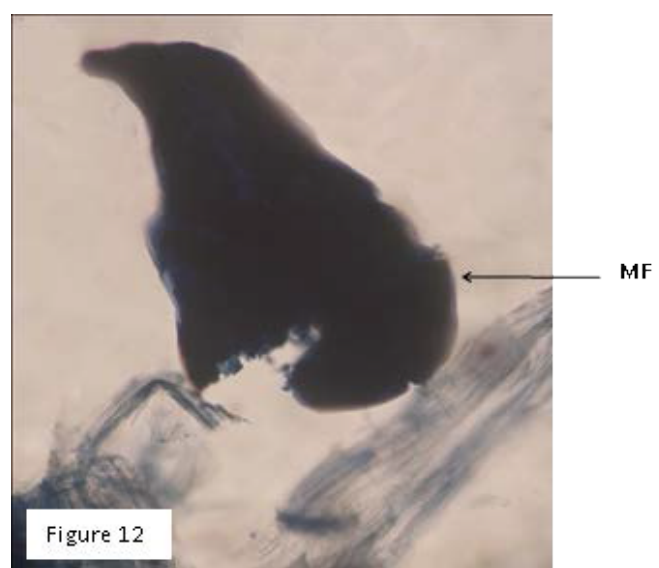

Figure 12: MF: Mature female.

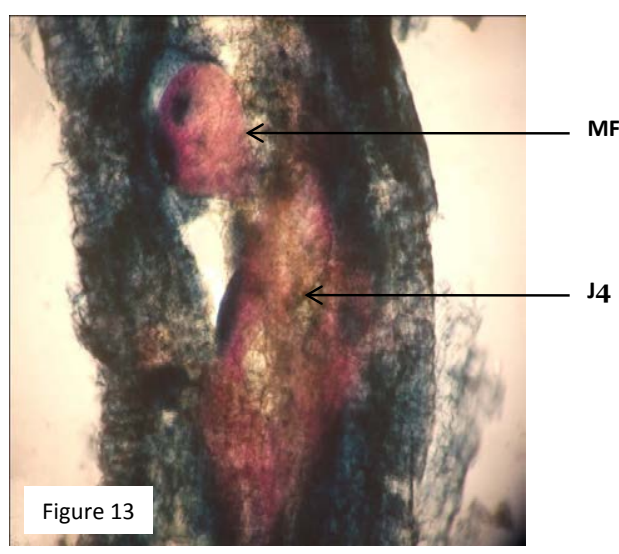

Figure 13: MF: Mature female J4: Fourth stage juvenile.

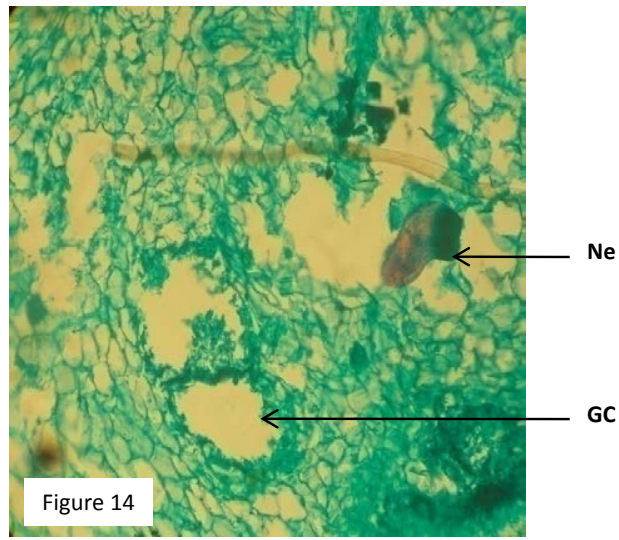

Figure 14: Ne: Nematode GC: Giant cell.

mature females causing epidermal necrosis were observed. Necrosis in the cortical tissues around the gelatinous matrix, or egg mass of the female nematode was frequent (Figure 16). A small cavity bordering the posterior part of the female was observed. After 30 days of inoculation, eggs were found embedded in the gelatinous matrix that were pushed out of the root surface. In several eggs first stage of juveniles were often observed inside the egg shells (Figure 19). The content of giant cells had deteriorated. Amount of abnormal xylem and phloem around the giant cell increased. Complete destruction in infected part of the root was observed (Figure 20). Large hypertrophied cells were found around the mature nematode. Vessel elements were seen as wide as giant cells. Several of the giant cells were found empty adjacent to the mature female nematode.

Some giant cells had loosely clumped cytoplasm enclosing hypertrophied nuclei; in these giant cells the cytoplasm was aggregated alongside the thickened cell walls. The stelar tissues within the galls appeared disorganized. The variable numbers of hypertrophied nuclei and nucleoli were noticed in the giant cells. The width of the giant cell complex was recorded as $221 \mu \mathrm{m}$. The shape and size of giant cells, in a giant cell complex were not uniform being ovate, elongated or of irregular shapes. The nuclei were larger than their normal size i.e. $15.47 \mu \mathrm{m}$. The dimension of mature female nematode was observed as $557 \times 440 \mu \mathrm{m}$. The cortical cells exhibited compact arrangement. Most of the giant cells were found surrounded by xylem and few with phloem. The width of the abnormal vessel elements increased upto $67 \mu \mathrm{m}$ and that of the normal one $40 \mu \mathrm{m}$. The head and the neck portions of the nematode were extended into the vascular system. The remaining oval

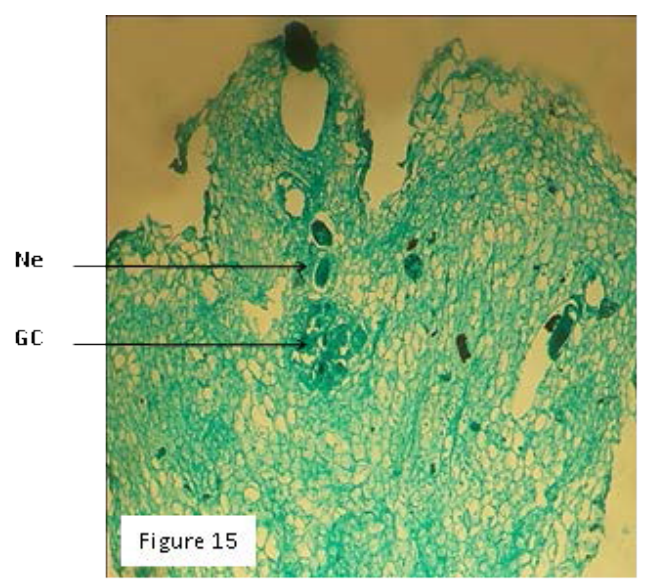

Figure 15: Ne: Nematode GC: Giant cell.

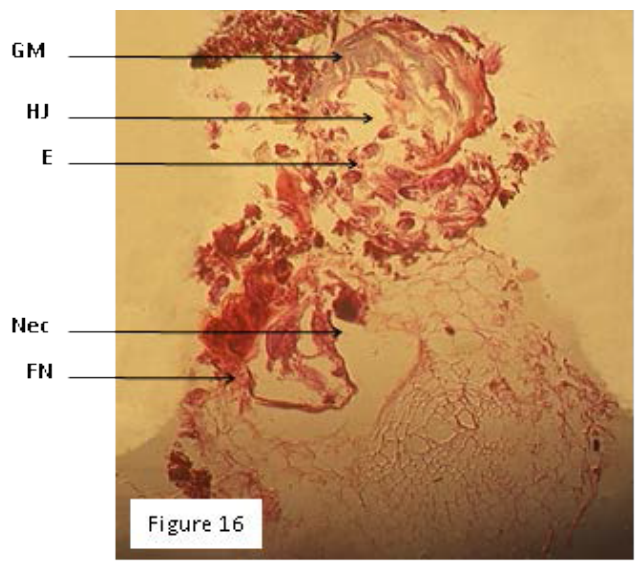

Figure 16: GM: Gelatinous matrix HJ: Hatched juveniles E: Eggs Nec: Necrosis FN: Female Nematode. 
Citation: Akhtar A, Hisamuddin (2015) Studies on the Histopathological Responses of Vigna Mungo towards Meloidogyne Incognita at Different Time Intervals. J Plant Pathol Microbiol 6: 319. doi:10.4172/2157-7471.1000319

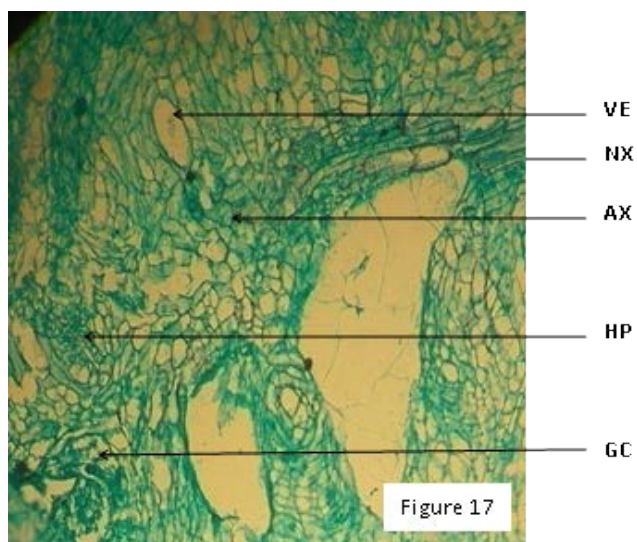

Figure 17: VE: Vessel element NX: Normal xylem AX: Abnormal xylem HP: Hyperplastied cells GC: Giant cell.

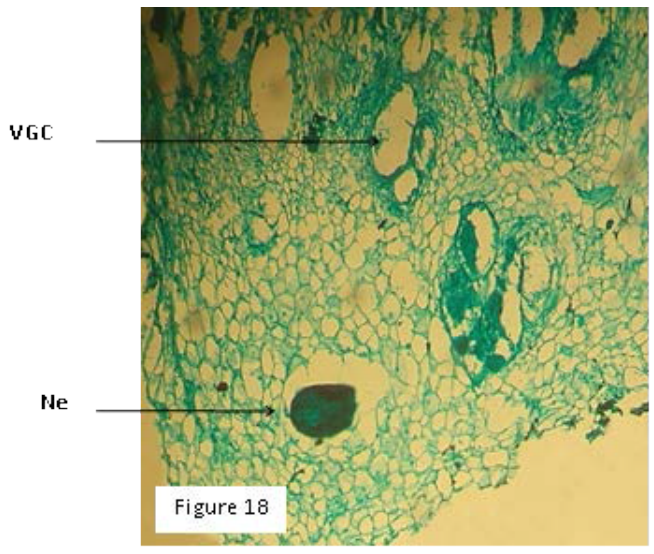

Figure 18: VGC: Vacuolated giant cell Ne: Nematode.

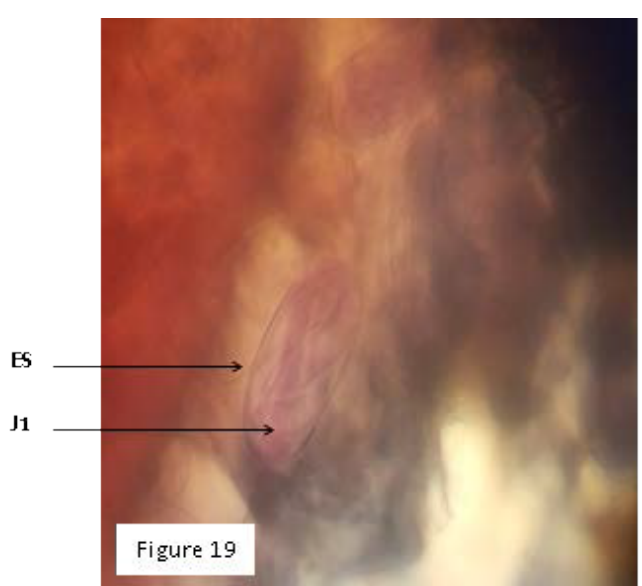

Figure 19: J1: Unhatched first-stage juvenile inside egg shell (ES).

shaped portion of the female was located in cortical tissue adjacent to the vascular system of the root. The diameter of egg sac was measured upto $304 \mu \mathrm{m}$. In several sections, females and egg masses were present in the superficial layer of the medullary region (Figure 21). Some eggs were hatched and the juveniles moved and entered cortex successfully
(Figure 22). Newly hatched juveniles functioned as secondary inoculum that resulted in severe infection (Figure 23).

\section{Discussion}

On examining the sections of Vigna mungo roots infected with the root-knot nematode, it was found that the nematode developed and reproduced normally within the root tissue. The juveniles of Meloidogyne incognita penetrated the roots by thrusting action of the stylet. In infected roots, great variation in the cell sizes was noticed, where some cells had become slightly enlarged and some had broken walls, while others were severely hypertrophied.

The penetration of juveniles into the plant root tip was observed within $24 \mathrm{~h}$ of inoculation. The juveniles entered the root through root tip by rupturing lateral walls and migrated into the inner tissues inter- and intracellularly. A cavity noticed around the juvenile body was probably used as passage to reach the zone of differentiation and elongation. Most of the cells along the path of the juveniles did not show any response of attack by the moving juvenile. In the zone of vascular differentiation, the juveniles were settled to get their nutrients. The parenchyma cells, in neighbourhood of the nematode, specially near the head or whole body, were induced to become enlarged.

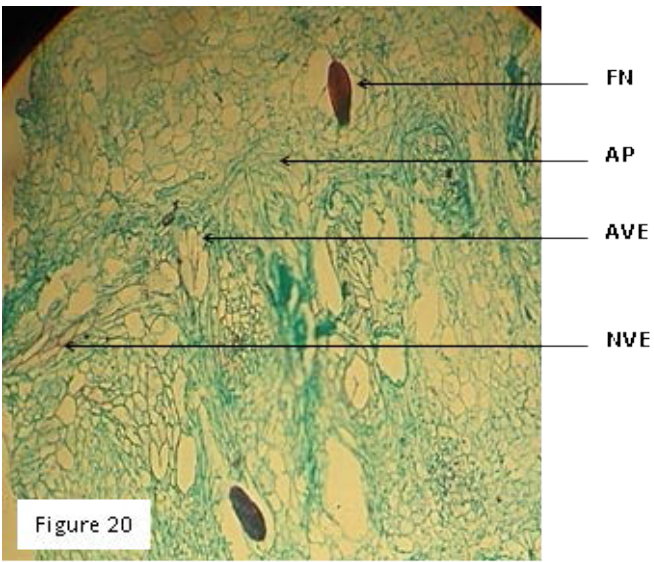

Figure 20: FN: Female nematode AP: Abnormal phloem AVE: Abnormal vessel element NVE: Normal vessel elements.

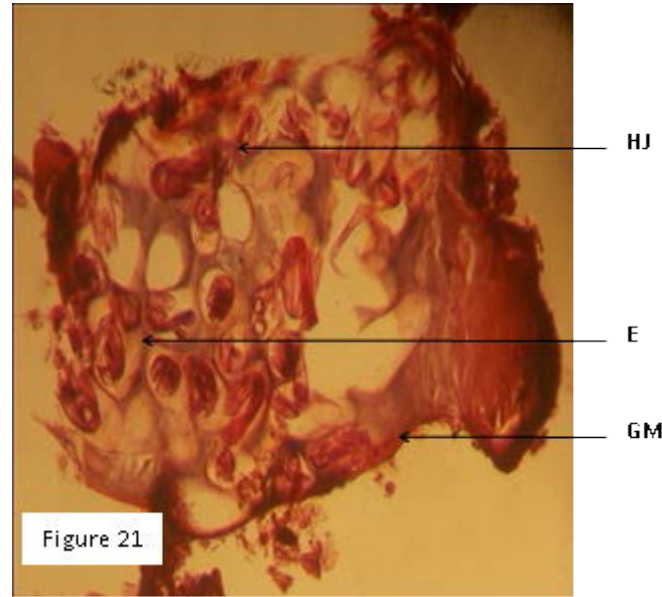

Figure 21: HJ: Hatched juvenile E: Eggs GM: Gelatinous matrix. 


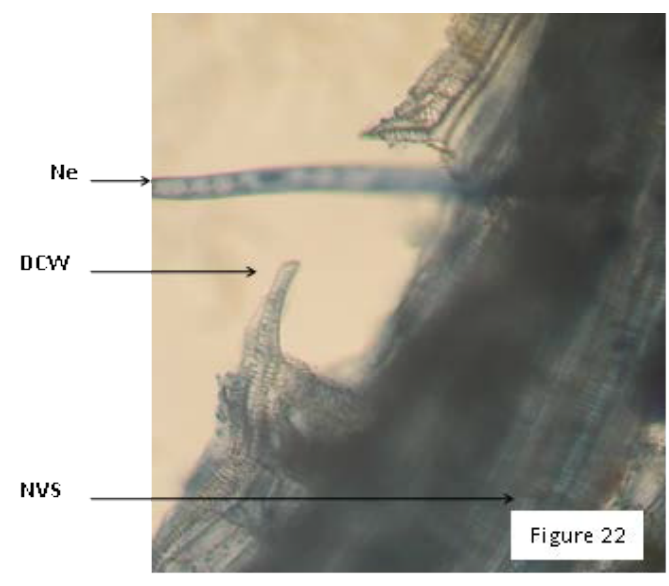

Figure 22: Ne: Nematode DCW: Disrupted cell wall NVS: Normal vascular strand.

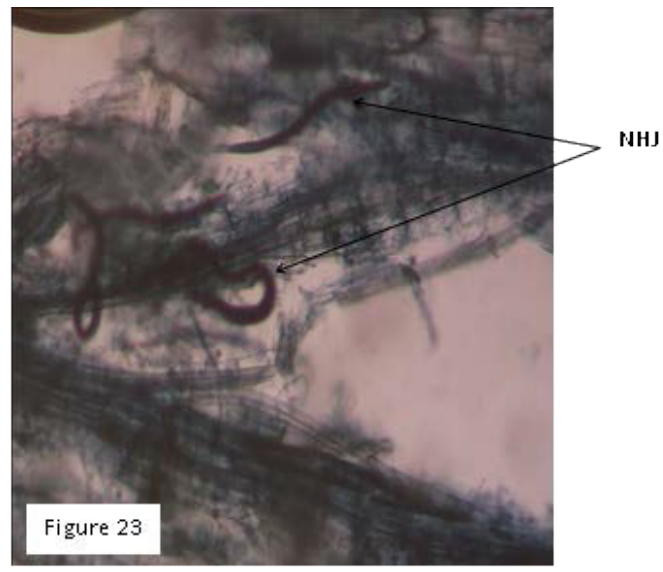

Figure 23: NHJ: Newly hatched juveniles.

Hypertrophy as a result of presence of the root-knot nematode has been reported by Bird [6], Mountain [9], Dropkin [10] on soybeans; Fawole [11] on white yam; Bhat and Hisamuddin [12] on bitter gourd; and Sayed et al. [13] on mango roots.

The entry point of juveniles was the root tip or from any other regions of the root in tomato [5]; back to the region of root hair formation in sweet potato [14] and in the region of cell differentiation and elongation in wheat [15].

After $48 \mathrm{~h}$ of exposure, the hypertrophied cells were noticed adjacent to the nematode head. Multinucleate condition was not prominent, although hypertrophy in certain cells observed, accompanied occurrence of dense cytoplasm. The cortical cells along the nematode body were found arranged compactly probably due to pressure exerted by the nematode body. The nematode induced the infected cells to make copious amount of cytoplasm that could be consumed by the nematode as nutrition. After inducing a feeding site, the nematode becomes sedentary [16].

After $72 \mathrm{~h}$ of exposure, enlargement of the affected cells was more pronounced; amount of the cytoplasm was found to be increased; it is essential in host parasite relation of the nematode with the plant. It appeared that the neighbouring cells provided nutrients to the affected cells. The cell wall of the developing giant cells became thick and showed ingrowths and projections that could help in absorption of the solutes. Dense and granular cytoplasm of enlarged cells indicated higher metabolic rate of the cell. One more evidence of higher metabolic rate was increase in number and size of nuclei. Niyaz et al. [17] reported cellular alteration in the infected root tissue of Eclipta alba due to infection caused by Meloidogyne incognita.

Hyperplasia of the tissues adjacent to the giant cells contributed in the formation of root galls [18]. The orientation of xylem and phloem elements was changed because of hypertrophic and hyperplstic reactions taking place in infected region. Due to production of cellular organelles at higher rate, inside the affected cell, accompanied with karyokinesis without cytokinesis, the size of infected cell was increased making the cytoplasm more dense as compared to after 24 and $48 \mathrm{~h}$ of nematode exposure. Jones and Payne [19] reported the first sign of giant cell formation due to the division of cells surrounding a larva. The number of nuclei appeared to increase by repeated mitosis without occurrence of cytokinesis.

After 5 days of nematode exposure cell multiplication, cell enlargement, thickness of cell wall, formation of dense cytoplasm, prominent nuclei and nucleoli was evidenced. These changes might have occurred to support the infection and in favor of the nematode. Increase in number and increase in size of the nuclei and the nucleoli indicated increased metabolic activity of the giant cell. The cytoplasm became dense due to increase in number of cellular organelles as well as increase in amount of cytoplasm. Increase in size of the giant cell at much rapid rate, as compared to uninfected cells, there was a need of strong cellular boundary so that the giant cell might not collapse. Due to this reason the cell wall of the giant cell became very thick. Increase in size of the nematodes was accompanied with increased in amount of cytoplasm. Increase in giant cell size and increase in body width of the nematode were associated with the vascular parenchymas on increasing the time of inoculation. Increases in size of giant cell together with the nematode were reported by Bird [6]; Endo [20]; Huang and Lin [21] and Bird et al. [22].

Jones and Payne [19] reported that the cytoplasmic density in the cell, next to the larvae was frequently increased as a result of increase in ribosome number, consequently, increasing the giant cell size continuously.

Plant growth of root-knot nematode infected plants was affected adversely; the plant exhibited stunting and yield loss due to deformation of vascular elements and change in orientation of xylem and phloem at the feeding site which limited translocation of the nutrients and water. The orientation of xylem and phloem elements was found changed and directed towards the nematode infected cells. The width and thickening of vessel elements increased and reached somewhat the size of giant cell. The giant cells were found surrounded by abnormal vascular elements to fulfill the nutrient demands of the giant cell and also the adjoining cells. Similar findings have been reported by Bhat and Hisamuddin [12].

After 10 days of nematode exposure, the giant cell size increased and it became multinucleate. The giant cell received enormous amount of metabolites and served as sink to provide nutrients to the developing nematode. The nematode moulted into third juvenile stage. Giant cells were found near the vascular strands especially the xylem as the metaxylem was the primary feeding site [23]. Some hypertrophied parenchyma cells changed into abnormal vessel elements to fulfill the nutrient demands of the growing nematode. Abrupt ending was due 
to change in orientation of vascular strains as a result of huge pressure applied by the developing nematode and the giant cells.

Bird [6] suggested that the giant cell wall became much thicker and irregularly surfaced containing all the normal polysaccharide components of the cell wall. Dropkin [10] proposed that the nematode and the root exchange signals following the infection, and such type of host response is the result of this exchange which must occur soon after the infective process begins. The cytoplasm became much dense having copious amount of proteins and RNA, for the synthesis of different cellular organelles (mitochondria, ribosomes, proplastids, golgi bodies and a dense endoplasmic reticulum) in a single nematode infected cell. The nuclei increased in number due to simultaneous mitotic divisions throughout the giant cell. It is assumed that as the nematode grows, the protein content in giant cells is increased to activate the giant cell to produce proper nutrition to the growing nematode [6].

After 15 days of exposure, the giant cell cytoplasm was more dense and granular containing enlarged nuclei with nucleoli. The giant cell complex was found associated with two or more nematodes at several locations. In such cases, the number of giant cells in the giant cell complex increased.

Bird [6] reported that infected cells contained more amount of protein, amino acids and nucleic acids than normal cells. Increase in size of infected cells resulted in proper growth of the nematode from $\mathrm{J}_{3}$ to $\mathrm{J}_{4}$ stage. Linford [24] reported that the nematode feeds on the giant cells within reach of it mobile head. It was assumed that after moulting of juveniles, the cytoplasm became more dense because of the greater demand of the food for its growth and survival. The nuclei of typical giant cell become enlarged and assume irregular shapes. The resulats of the experiment confirmed enlargement of nuclei and nucleoli. Sayed et al. [13] proposed that disruption of cortical cells due to migration of larvae of $M$. javanica partly contributed in the development of the knots in mango roots. Proliferation of abnormal xylem around the giant cells provided essential elements to the nematode through the giant cells. Formation of large number of giant cells lead to the destruction of feeder roots completely resulting in reduction of water absorption and nutrients from the soil that ultimately affected the plant growth.

Due to higher demand by the nematode vacuolation in the giant cells was resulted after 21 days of exposure of nematode. The giant cell cytoplasm appeared to be aggregated towards the periphery or towards the centre. The number of nuclei considerably decreased that confirmed that the nematode consumed the protoplasm of the giant cells. The number of abnormal vessel elements, with reticulate wall thickenings increased to meet the demand of nutrients by the giant cells. Some vessel elements became as wide as giant cell to fulfill the nutrient requirement at faster rate.

The giant cell complexes were observed in the cortical region as well as stelar region. The nuclei and nucleoli stained densely and concentrated at the centre. Due to amoeboid and irregular shapes, surface area of the nuclei is increased [25]. Infected roots produced large number of lateral branches to compensate the loss of water and nutrients [5,14]. Siddiqui and Taylor [15] reported that the initial pathological alterations in giant cell formation consisted of hypertrophy in protophloem and protoxylem cells, their nuclei and nucleoli. The vacuolation in some giant cells was also noticed due to the excessive feeding by the nematode.

After 25 days of nematode exposure, it was found that the nematode attained its full size and assumed oval shape. The giant cell complex adjoining the mature female became thick walled. The number of nuclei decreased in the giant cells due to higher demand by the nematode. As the days increased the amount of cytoplasm decreased. Some giant cells changed into vessel like elements to prevent collapsing of galled tissues by the deposition of lignified secondary wall material [14].

According to Bird and Loveys [26] and McClure [27] the developing female acts as a metabolic sink in infected plants. The photosynthetic products are mobilized from the shoots towards the roots particularly to the giant cells. Meon et al. [28] reported that mobilization and accumulation of these substances reached to their maximum extent when the adult females commenced egg laying. The giant cells containing cytoplasm provided nutrition the developing juveniles causing secondary infection. Feeding of $M$. incognita on vascular elements would have impaired the absorption and translocation of water and nutrients and ultimately caused reduction in the growth of the plants as reported by Khan et al. [29]. The giant cells were reported as vacuolated at this stage due to the continuous feeding by mature female that laid eggs. The giant cells were under the process of liquefaction and the cells of the cortex were full of matrix causing disruption. The disruption of cortical cells, due to migration of larvae, partly contributed in the development of knots in mango roots. Khan et al. [30] reported histopathological changes in the roots of apple due to root-knot nematode, Meloidogyne incognita, infection. Several sections of females and egg masses were present in the superficial layer of the medullary region. After getting continuous supply of food, the nematode became mature and pyriform surrounded by abnormal xylem elements having wide diameter. The nearby parenchymatous cells around the giant cells changed into vessel like elements to provide water and minerals towards nematode through giant cells.

After 30 days of nematode exposure, some of the giant cells became vacuolated and in most of the giant cells the cytoplasm, having prominent nuclei and nucleoli was found reduced due to consumption by the mature nematode. The lesser amount of cytoplasm, found in the giant cells, might be due to the higher rate of withdrawal by the nematode than the rate of its production. From this observation it is clear that the nematode obtained its nutrition directly from the giant cells. Occurrence of the thick cell wall of the giant cell prevented it from bursting. The giant cells were surrounded by abnormal xylem and phloem. The abnormal xylem around the giant cells was thought to be a protective covering for the giant cells as was proposed by Hisamuddin [31]. Bhat and Hisamuddin [12] concluded that hypertrophied and hyperplastied cells near the giant cell pushed the vascular stands away from their normal position to change the orientation of the vascular elements. The mature females laid eggs successfully after getting continuous supply of nutrition from the giant cells. The parenchyma cells adjacent to the egg masses became distorted due to pressure exerted by the egg mass. Orion et al. [32] revealed that a small cavity bordering the posterior portion of the female and fragments of the cell walls engulfed by the gelatinous matrix due to its enzymatic activity and observed that eggs deposited by the nematode female were embedded in the gelatinous matrix and pushed through the canal to form the egg mass on the gall surface. The eggs were deposited in the gelatinous matrix and pushed onto the surface of the root. The giant cells adjacent to the mature females became empty and transformed into vessel like elements. From the freshly laid eggs, second stage juveniles were emerged, which migrated and infected other sites of the root tissue. The cycle of secondary infection was started again. 
Citation: Akhtar A, Hisamuddin (2015) Studies on the Histopathological Responses of Vigna Mungo towards Meloidogyne Incognita at Different Time Intervals. J Plant Pathol Microbiol 6: 319. doi:10.4172/2157-7471.1000319

\section{References}

1. Hussey RS (1989) Disease-inducing secretions of plant parasitic nematodes Annu Rev Phytopath 27: 123-141.

2. Davis EL, Hussey RS, Baum TJ, Bakker J, Schots A, et al. (2000) Nematode parasitism genes. Annu Rev Phytopathol 38: 365-396.

3. Caillaud MC, Dubreuil G, Quentin M, Perfus-Barbeoch L, Lecomte $P$, et al. (2008) Root-knot nematodes manipulate plant cell functions during a compatible interaction. J Plant Physiol 165: 104-113.

4. Bird AF (1968) Changes associated with parasitism in nematode. IV Cytochemical studies on the ampulla of the dorsal oesophageal gland of Meloidogyne javanica and on exudations of the buccal cavity. J Parasitol 54: 879-890.

5. Christie JR (1936) The development of root-knot nematode galls. Phytopathology 26: 1-22.

6. Bird AF (1961) The ultrastructure and histochemistry of a nematode-induced giant cell. J Biophys Biochem Cytol 11: 701-715.

7. Johansen DA (1940) Plant Microtecniques. Mc Graw-Hill, New Book Co. New York, USA

8. Sass JE (1951) Botanical Microtechniques. lowa State College Press, Ames, lowa.

9. Mountain WB (1960) Theoretical considerations of plant nematode relationships. In: Sasser, JN Jenkins, WR, editors. Nematology. University North Carolina Press, Chapel Hill, pp. 419-421.

10. Dropkin VH (1969) Cellular responses of plants to nematode infections. Annu Rev Phytopathol 7: 101-122.

11. Fawole B (1988) Histopathology of Root-knot Nematode (Meloidogyne incognita) Infection on White Yam (Dioscorea rotundata) Tubers. J Nemato 20: 23-28.

12. Bhat MY, Hisamuddin (2010) The effect of Meloidogyne incognita on the histopathology of Momordica charantia roots. Arch Phytopathol Plant Protect 43: 1619-1624.

13. Sayed M, Khan A, Khatoon N, Bilqees FM, Samad MA (2010) Histopathology of mango roots infected by root-knot nematode. Pak J Nematol 28: 335-340.

14. Krusberg LR, Neilsen LW (1958) Pathogenesis of root-knot nematodes to the Porto Rico variety of sweet potato. Phytopathology 48: 30-39.

15. Siddiqui IA, Taylor DP (1970) Histopathogenesis of Galls Induced by Meloidogyne naasi in Wheat Roots. J Nematol 2: 239-247.

16. Jenkins WR, Taylor DP (1967) Plant Nematology. Reinhold Publishing Corp. New York,USA.
17. Niyaz T, Azam T, Hisamuddin (2011) Histological responses and damage potential in roots of Eclipta alba L. caused by Meloidogyne incognita. Libyan Agriculture Research Center Journal International 2: 118-122.

18. Vovlas N, Lucarelli G, Sasanelli N, Troccoli A, Papajova I, et al. (2008) Pathogenicity and host-parasite relationships of the root-knot nematode Meloidogyne incognita on celery. Plant Pathol 57: 981-987.

19. Jones MG, Payne HL (1978) Early stages of nematode-induced giant-cel formation in roots of Impatiens balsamina. J Nematol 10: 70-84.

20. Endo BY (1964) Penetration and development of Heterodera glycines in soybean roots and related anatomical changes. Phytopathology 54: 79-88.

21. Huang CS, Lin HL (1970) Pathological responses of stems to root-knot nematode infection. Botanical bulletin of Academia Sinica 11: 79-87.

22. Bird AF, Downton WJS, Hawker JS (1975) Cellulase secretion by second stage larvae of the root-knot nematode (Meloidogyne javanica). Marcellia 38: 165169

23. Linford MB (1941) Parasitism of the root-knot nematode in leaves and stems Phytopathology 31: 634-48.

24. Linford MB (1937) The feeding of root-knot nematode in root tissue and nutrient solution. Phytopathology 27: 824-835.

25. Huang CS, Maggenti AR (1969) Mitotic aberrations and nuclear changes of developing giant cells in Vicia faba caused by root-knot nematode, Meloidogyne javanica. Phytophathology 59: 447-455.

26. Bird AF, Loveys BR (1975) The Incorporation of Photosynthates by Meloidogyne javanica. J Nematol 7: 111-113.

27. McClure MA (1977) Meloidogyne incognita: a metabolic sink. J Nematol 9: 8890.

28. Meon S, Wallace HR, Fisher JM (1978) Water relations of tomato (Lycopersicon esculentum Mill. $\mathrm{cv}$. Early dwarf red) infected with Meloidogyne javanica (Treub.) Chitwood. Physiol Plant Pathol 13: 275-281.

29. Khan RM, Khan MW, Khan AM (1985) Cohabitation of Meloidogyne incognita and Rotylenchulus reniformis in tomato roots and effect on multiplication and plant growth. Nematol Medit 13: 153-159.

30. Khan A, Khatoon N, Bilqees FM, Mehboob S (2010) Histopathology of apple (Malus pumila Mill.) root infected with root-knot nematode (Meloidogyne incognita) Sarhad J Agric 26: 61-64.

31. Hisamuddin (1992) Histopathological studies on the roots of Luffa cylindrica infected with Meloidogyne incognita. Ph.D Thesis, AMU, Aligarh.

32. Orion D, Loots GC, Orion T (1987) Cell lysis activity of Meloidogyne gelatinous matrix. Revue Nematol 10: 463-465 